\title{
Labor Planning of Farmer Households
}

\author{
Endang Yektiningsih ${ }^{1}$, Sigit Dwi Nugroho, Eko \\ Nurhadi \\ Department of Agribusiness \\ Universitas Pembangunan Nasional "Veteran" Jawa Timur \\ Surabaya, Indonesia \\ 1endangyn@gmail.com
}

\author{
Sugiarto \\ Department of Informatics Engineering, \\ Faculty of Computer \\ Universitas Pembangunan Nasional "Veteran" Jawa Timur \\ Surabaya, Indonesia
}

\begin{abstract}
This research aims to identify the working time allocation of vegetable farm households and arrange a labor planning model specially at vegetable farming households. This research was held in Tutur Sub-District, Pasuruan Regency with a total sample of vegetable farming households as many as 60 persons. The results of the study showed that vegetable farmers' households did not use wage labor system, all activities were carried out by family workers. Workforce planning is structured based on problems and root problems that come from internal and external factors and then made by a matrix that leads to workforce planning. Labor planning made by considering the characteristics of farm households and developing technologies that have been mastered and innovated.
\end{abstract}

Keywords: Planning, Labor, Farmer Household, Vegetables.

\section{INTRODUCTION}

Indonesia is one of the countries in the world whose population is relatively high which it is reflected in the development of the number of households both in urban and rural areas. Based on the Agricultural Census in 2003 the number of households in Indonesia reached 52,904,295 in urban areas as many as 22,704,483 (42.92\%) and in rural areas were $30,199,812(57.08 \%)$. Of this number, which are classified as agricultural households in Indonesia as many as $24,868,875$ in urban areas as many as 3,727,402 (14.99\%) and agricultural households in rural areas as much as $21,141,273$ $(85.01 \%)$. [1;2]

The agricultural sector is the dominant labor field both in East Java and also in Indonesia, although sometimes it has increased and decreased. In 2009 agricultural labor in East Java experienced an increase of 2.49 percent, but then declined in 2010 by 3.03 percent. [3;4]

These fluctuations indicate the flow of labors entering and leaving between the agricultural sector and other sectors. The characteristic of the agricultural sector that does not require many conditions, makes alternative work that she can be used as a main job and or side by side with non-agricultural work. Although it is fluctuating, it will not shift the agricultural sector as the main employment for most of the population in Indonesia $[4 ; 5]$.

Generally, the working time of farmers is still not optimum because there is still a lot of leisure time that has not been utilized for productive activities, thus affecting the income of farmers who are still low [6;7]. Table 1 presents the number of people aged more than 15 years who work in the agricultural sector based on working hours per week in 2008-2010.

TABLE I. NUMBER OF WORKING HOURS PER WEEK IN INDONESIA

\begin{tabular}{|c|c|c|c|}
\hline \multirow{2}{*}{$\begin{array}{c}\text { Number of } \\
\text { Working Hours } \\
\text { per Week }\end{array}$} & \multicolumn{3}{|c|}{$\begin{array}{c}\text { Number of Indonesians working at the age } \\
\text { of more than 15 years (million) }\end{array}$} \\
\cline { 2 - 4 } & $\mathbf{2 0 0 8}$ & $\mathbf{2 0 0 9}$ & $\mathbf{2 0 1 0}$ \\
\hline $1-7$ & 1.23 & 1.31 & 1.20 \\
\hline $8-14$ & 4.41 & 4.56 & 4.59 \\
\hline $15-24$ & 11.23 & 11.64 & 12.48 \\
\hline $26-34$ & 14.23 & 14.6 & 15.00 \\
\hline $25-44$ & 31.11 & 31.57 & 33.27 \\
\hline $45+$ & 71.44 & 73.30 & 74.94 \\
\hline
\end{tabular}

Source: TNP2K, 2010

This research purposes are: (1) To identify working time allocation of vegetable farm households in Tutur Sub-District, and (2) To developing model of the use of labor planning in vegetable farming households in Tutur Sub-District.

\section{RESEARCH METHODS}

The study was conducted in Tutur Sub-District, Pasuruan Regency by taking one of the villages namely Ngadirejo Village as the center of vegetable production.

The main objective of this research is to find out and analyze the labor use in the farm household especially in the households decision of the farmer in managing the labor, both family labor and hire labor. Therefore, the sample taken is a vegetables farmer household. The number of samples is 60 farmer households that taken randomly. The analytical method used is APAS method, which is a method for the planning agribusimess which based on agrosystem [8].

\section{RESULTS AND DISCUSSION}

A. Labor Situation in Vegetable Farmer Households in Tutur Sub-district, Pasuruan Regency.

Labor is a production facility that cannot be separated but has different characteristics between regions and between commodities. The use of labor for vegetable farming in Ngadirejo Village, Tutur Sub-district has the characteristics of 
not using labor for rent (wages), but each farm household does its own farm on average. This is due to lack of labor in the countryside and the distance from farming to other areas. In addition, the average education of the residents of Ngadirejo Village who only graduated from Elementary School made the labor force not absorbed in other jobs so that residents preferred to work on their own farms. Table 1 illustrates the state of employment in farming farmer households in Ngadirejo Village, Tutur Sub-district.

TABLE II. AVERAGE USE OF LABOR IN VEGETABLE FARMING IN NGADIREJO VILLAGE, TUTUR SUB-DISTRICT

\begin{tabular}{|c|l|c|c|c|}
\hline No & $\begin{array}{c}\text { Type of } \\
\text { Vegetables } \\
\text { Commodity }\end{array}$ & $\begin{array}{c}\text { Number of } \\
\text { Head } \\
\text { Family } \\
\text { work day } \\
\text { (HOK) }\end{array}$ & $\begin{array}{c}\text { Number of } \\
\text { Family } \\
\text { Member } \\
\text { work day } \\
\text { (HOK) }\end{array}$ & $\begin{array}{c}\text { Total } \\
\text { of work } \\
\text { day } \\
\text { (HOK) }\end{array}$ \\
\hline 1 & Cultivating & 14 & 8 & 22 \\
\hline 2 & Planting & 7 & 7 & 14 \\
\hline 3 & Maintenance & 2 & 4 & 6 \\
\hline 4 & Harvesting & 7 & 7 & 14 \\
\hline 5 & Marketing & 6 & 4 & 10 \\
\hline & TOTAL & 36 & 30 & 66 \\
\hline
\end{tabular}

Source: Primary Data Analysis

The average of vegetable farming households in Ngadirejo Village use their own family labor consisting of head of family, wife, and their children who are adults. There is no labor family use for off-farm activities because all work time has been devoted to work on his own farm. The average of head family work time is higher than the working time of family members, which is $54.55 \%$, while family members only use $45.45 \%$ of the total time spent using family labor.

The most use of working time is for land processing activities which consist of hoeing and cultivating the soil. The different characteristics comparing between Ngadirejo village and another is about the peasant woman participates in processing the soil (hoeing). Sometimes the woman farmer have to cultivate the land even though she is menstruating or a few months after giving birth.

The smallest allocation of time is for maintenance activities, namely the activities of weeding plants [9].

\section{B. Labor Planning in Vegetable Farmers Households}

Planning is important for the success of a business. In subsistence farming, farming planning is rarely done, generally farming activities are carried out for generations without any records and planning. As a result of the absence of planning, the risk of failure or loss is higher, especially if it is associated with the problem of natural influence. To reduce the risk of failure it is need necessary to analyze the use of labor planning on vegetable farming. [10;11]

In this analysis the APAS (Agrosystem Planning and Development Analysis) method is used but is limited to the analysis of the laborforce so that it produces a good laborforce planning. APAS consists of:
1. Position Analysis and Agrosystem Performance (APKAS)

In APKAS it actually analyzes all aspects of the resources that are owned, but in this study focused on the analysis of workforce planning by "understanding the situation of the case", which is a way of describing the state of labor resources owned by households according to ualitative and quantitative components.

Based on the data collected, it was obtained the results of understanding the situation of the vegetable farm household labors in Ngadirejo Village as follows.

TABLE III. RESULTS OF POSITION ANALYSIS AND AGROSYSTEM PERFORMANCE (APKAS) FOR LABORS IN VEGETABLE FARMERS' HOUSEHOLDS.

\begin{tabular}{|c|l|c|c|}
\hline No & \multicolumn{1}{|c|}{$\begin{array}{c}\text { Understanding } \\
\text { Situation }\end{array}$} & $\begin{array}{c}\text { Quantitative } \\
\text { (Score) }\end{array}$ & $\begin{array}{c}\text { Qualitative } \\
\text { (Unit) }\end{array}$ \\
\hline 1 & Age of Labor & 3 & 49 years \\
\hline 2 & $\%$-ase Male Gender & 2 & $56 \%$ \\
\hline 3 & $\begin{array}{l}\text { Working Time for } \\
\text { Farming }\end{array}$ & 4 & 7 hours/day \\
\hline 4 & Number of Labor & 3 & 3 peoples \\
\hline 5 & Labor education & 2 & $\begin{array}{c}\text { Elementary } \\
\text { school }\end{array}$ \\
\hline
\end{tabular}

Source: Primary Data Analysis

\section{Analysis of Agrosystem Development Problems (AMPAS)}

This analysis is carried out by identifying various problems faced by vegetable farming households which are then linked to each problem with a series of causal relationships so as to form a problem tree diagram. This analysis aims to assess deficiencies, weaknesses and dissatisfaction in the components of agrosystem position and performance and then formulated as a problem or problem. AMPAS analysis results are presented in Figure 1 below.

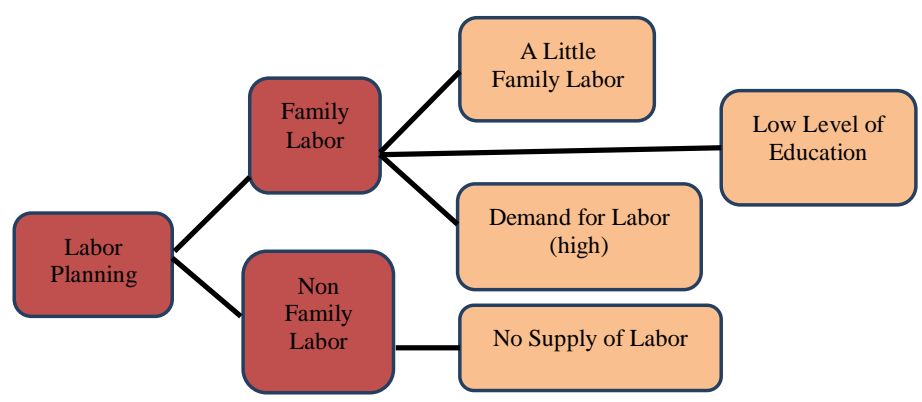

Fig. 1. Results of Analysis of Agrosystem Development Problems (AMPAS) for Labor Planning in Vegetable Farmers' Households in Ngadirejo Village

Figure 1 shows that in preparing planning must see the problems faced, both internally and externally. The internal problem is the high demand for labor, while the external is the small supply of labor. The root of the problem of high labor demand are: (a) the number of family members who are productive age is too little, (b) the low leisure time of the family head and family members so that there is no time to increase income through working off-farm and non-farm. $[12 ; 13]$ 


\section{Agrosystem Development Target Analysis (ASPAS)}

This analysis outlines the goals to be achieved by reversing the negative pattern of positive patterned statements that reflect the future state when the problem is solved, which is then described as a series of action relations of results on a diagram of the target tree. Further estimating the follow-up effects of achieving the main goal of agrosystem achievements. The goals to be achieved in solving employment problems in vegetable farming households in Ngadirejo Village, Tutur Sub-district are prepared with the following ASPAS analysis.

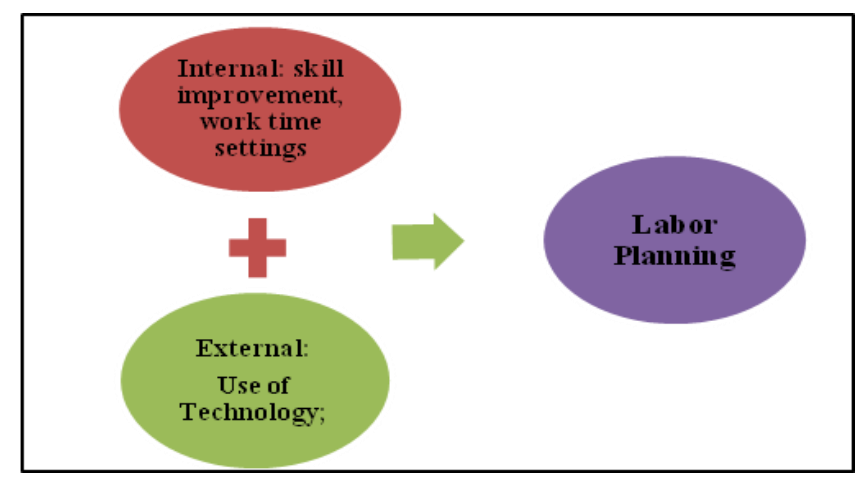

Fig. 2. Results of Analysis of Objectives to be Achieved (ASPAS) for Labor Planning in Vegetable Farmers Household in Ngadirejo Village.

Figure 2 shows that the solution to labor problems in vegetable farming in Ngadirejo Village is arranged based on the objectives to be achieved from various problems faced, so that the planning of workforce is based on problem solving. [14] [15]

\section{Analysis of Alternative Agrosystem Development Actions (A2TPAS)}

This analysis outlines what actions are taken to achieve the previously set goals. In this case the target to be achieved is the arrangement of labor planning in vegetable farming households in Ngadirejo Village, Tutur Subdistrict. The analysis uses Decision Analysis (AK) which evaluates alternative actions to obtain the best alternative.

The alternative actions that will be carried out are:

a. Use alternative technologies other than those proposed from vegetable farming households.

b. Calculate farm household income and expenditure with the old model of labor use with the proposed one

c. Calculate the work time allocation for each member of the farm household to get accurate data between work time and free time[16].

\section{Agrosystem Development Matrix (MPAS)}

This matrix outlines the chosen alternatives from the results of the decision analysis and identifies each target against the measurement of the objectives and specifications of the information system for managerial control and determines the amount of cost requirements and the facilities needed to carry out these actions.

The matrix of the planning of laborforce in vegetable plant households is arranged as follows:

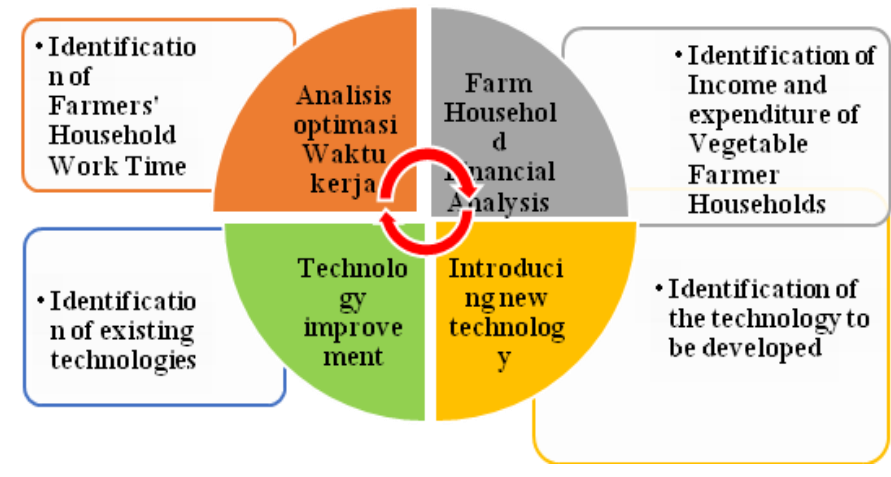

Fig. 3. Matrix of Results of Analysis of Objectives to be Achieved (ASPAS) for Labor Planning in Vegetable Farmers Households in Ngadirejo Village

\section{Agrosystem Development Action Plan (RTPAS)}

This matrix outlines the alternatives chosen from the results of the decision analysis and identifies each target against the size of the achievement of the information system objectives and specifications for managerial control. As well as determining the amount of cost and facilities needed to carry out the action.

In this RTPAS the matrix is prepared based on the calculation of costs and facilities needed for manpower planning in vegetable farming households in Ngadirejo Village, Tutur Sub-district. The results of this analysis make consideration of the decision of the farm household to compile the work plan of the vegetable farm household.

\section{CONCLUSION}

1. The characteristics of employment in vegetable farming households in Ngadirejo Village, Tutur Sub-district, Pasuruan Regency, are:

a. Using family labor

b. All family members who are in productive age and no school will help in working on their vegetable farming

c. The highest work time allocation is found in the head of the family, wife, and family member.

d. There is no labor planning in farm households, they are using hereditary methods.

2. Labor planning in vegetable farming households in Ngadirejo Village is prepared using the APAS Method with the following stages:

a. The APKAS method produces problems and root causes in the preparation of workforce planning

b. AMPAS method produces problem solving methods based on the root of the problem found. 
c. The ASPAS method produces alternative problem solving for the preparation of labor planning in vegetable farm households in Ngadirejo Village.

d. The A2TPAS method produces a technical problem solving matrix in the preparation of labor planning in vegetable farm households in Ngadirejo Village, Tutur Sub-district.

e. The MPAS method produces an economical problem solving matrix in the preparation of labor planning in vegetable farm households in Ngadirejo Village, Tutur Sub-district.

\section{ACKNOWLEDGMENT}

I would like to express my gratitude to Universitas Pembangunan Nasional "Veteran" Jawa Timur who helped the research fund and to the Green Team farmer group in Ngadirejo village, Tutur Sub-district, Pasuruan, East Java for all the support in this research.

\section{REFERENCES}

[1] A. Abdulai and P.R. Punya, "Estimating Labor Supply of Farm Households Under Nonseparability: Empirical Evidence From Nepal," Agric. Econ., vol. 22, pp. 309 - 320, 2000.

[2] Badan Pusat Statistik, "Employment Statistics in Indonesia," unpublished, 2013.

[3] D. Benjamin, "Household Composition, Labor Markets, and Labor Demand: Testing For Separation in Agricultural Household Models," Econometrica, vol. 60, pp. 16, 1992.
[4] J.L. Findeis and D.A. Lass, "Labor Decisions by Agricultural Households: Interrelationships between Labor Supply and Hired Labor Demand Off-farm," Northeastern J. Agric. Resour. Econ., vol. 18, pp. 149-159, 1989.

[5] S. Fukui and H.M. Jangkung, "Separation Testing Hypothesis in Rural Java: Revisited," J. Rural Probl., vol. 42, pp. 224-236, 2006.

[6] S. Hess, "The Demand for Seasonal Farm Labor from Central- and Eastern European Countries in German Agriculture," Agric. Eng. Int. CIGR J., vol. 8, pp. 1-10, 2006.

[7] A. Kimhi, "Is Part-Time Farming Really a Step in The Way Out of Agriculture," Am. J. Agric. Econ., vol. 82, pp. 38-48, 2000.

[8] A.K. Mishra, "Time Allocation by Farm Households and Endogenous Farm Structure: Implication for Agriculture Policy," unpublished, 1998.

[9] C. Nakajima, "Subsistence and Commercial Family Farms: Some Theoritical Models of Subjective Equilibrium" in Subsistence Agriculture and Economic Development, C.R. Wharton Jr, Editor, Chicago: Aldine Publishing Company, 1970.

[10] J. Perry and B. Hoppe, "Estimates Farm Household Income Provides Additional Perspective On Farm Families," unpublished, 1993.

[11] A. Salim, "APAS (Analisis Perencanaan dan Pengembangan Arosistem)", available at:

http://agussalimnolsembilan.blogspot.com/2012/04/apas-analisisperencanaan-dan.htm

[12] W. Simpson and M. Kapitany, “The Off-Farm Work Behavior of Farm Operators," Am. J. Agric. Econ., vol. 65, pp. 801-806, 1983.

[13] T. Sonoda and M. Yoshimiro, "Effects on the Internal Wage on Output Supply: A Structural Estimation For Japanese Rice Farmers," Am. J. Agric. Econ., vol. 81, pp. 131-143, 1999.

[14] E. Yektiningsih, "The Decision of Woman Farmers in Implementing Urban Farming Program in Surabaya," Proceedings of International Conference on Agriculture (ICA-2013), 2013.

[15] E. Yektiningsih, A. Purnawati, R. Hidayat, and Sugiarto, “The Response of Farmers to the Implementation of Agricultural Marketing Information System," J. Rev. Facul. Agron., vol. 35, pp. 2, 2018.

[16] A.K. Zakaria, "Performance of Employment Opportunities in the Agriculture Sector and Its Impact on Rural Household Income. Cases in Tarusa and Kalasebo Villages, Sumbawa Regency, NTB, 2005. 